\title{
Kepuasan, Kepercayaan, Komitmen dan Loyalitas Mahasiswa
}

\author{
Asep Suhendar ${ }^{(1)}$ \\ Eveline Yeremia ${ }^{(2)}$ \\ Verra Aprilianty ${ }^{(3)}$ \\ Universitas Kristen Maranatha (1) (2) (3) \\ Asepsuhendarners@gmail.com ${ }^{(1)}$ \\ Yeremiaeveline@gmail.com ${ }^{(2)}$ \\ Verraaprilianty@gmail.com ${ }^{(3)}$
}

\begin{abstract}
Universities in Indonesia, including in Bandung, inspite of being a social organization, it must be able to compete with the foreign universities. Internal Marketing approach is one way to analyze the strengths of Internal Resources owned by a service company. This study examines the mediating role of satisfaction in trust and commitment relationships with loyalty in a University in Bandung. Sample size is 162 respondents whom taken by self-administered questionnaires from bureau academic staff of $X$ University. This research shows that satisfaction is still a major consideration that cause loyalty, since there is a fully mediating role of satisfaction in trust and loyalty relationship. It means that trust should be elaborated into satisfaction firstly before turn into loyalty. The authors also make some recommendations, especially the recommendation that satisfaction is still an important factor in determining loyalty, It means that a universities in Bandung should developed employees' satisfaction to survive in the borderless economic competition.
\end{abstract}

Keywords: Internal Marketing; Trust, Loyalty; Satisfaction; Commitment; Mediating Role

\begin{abstract}
ABSTRAK
Selain menjadi organisasi kemasyarakatan, perguruan tinggi di Indonesia termasuk di Bandung, harus mampu bersaing dengan perguruan tinggi asing. Pendekatan Pemasaran Internal merupakan salah satu cara untuk menganalisis kekuatan Sumber Daya Internal yang dimiliki oleh suatu perusahaan jasa seperti perguruan tinggi. Penelitian ini menguji peran mediasi hubungan kepercayaan dan komitmen dengan loyalitas pada sebuah Universitas di Bandung. Sampel penelitian adalah 162 responden yang diambil dengan metode kuesioner dari staf departemen akademik Universitas X. Hasil penelitian menunjukkan bahwa kepuasan masih menjadi pertimbangan utama bagi loyalitas, karena terdapat peran mediasi penuh dari kepuasan dalam kepercayaan dan hubungan loyalitas. Artinya kepercayaan harus dielaborasi menjadi kepuasan terlebih dahulu sebelum berubah menjadi loyalitas. Perguruan tinggi di kota Bandung harus mengembangkan kepuasan karyawan untuk bertahan dalam persaingan ekonomi. Penulis juga memberikan beberapa rekomendasi terkait kepuasan yang masih menjadi faktor penting dalam menentukan loyalitas. Untuk itu, perguruan tinggi di kota Bandung harus mengembangkan kepuasan karyawan agar dapat bertahan dalam persaingan ekonomi.
\end{abstract}

Kata kunci: Pemasaran Internal; Kepercayaan; Kepuasan; Komitmen; Loyalitas; Peran Mediasi. 


\section{PENDAHULUAN}

Saat ini perdagangan internasional dan globalisasi merupakan hal penting, baik dalam dunia politik maupun ekonomi. Dengan adanya perdagangan internasional tentu akan tercipta sebuah persaingan antar negara. Dalam persaingan di masa yang akan datang, badan usaha termasuk perguruan tinggi perlu mengembangkan keunggulan kompetitif (Syahruddin et al., 2017; Dewi dan Darma, 2019; Dharma dan Noviana, 2020; Priskila dan Darma, 2020; Shavitri dan Darma, 2020; Sudiwedani dan Darma, 2020; Handayani dan Darma, 2018; Handayani dan Darma, 2021; Murti dan Darma, 2021; Yong dan Darma, 2020; Rivaldo et al., 2021). Perguruan tinggi di Indonesia, termasuk di Bandung, meskipun sebagai organisasi kemasyarakatan harus mampu bersaing dengan perguruan tinggi luar negeri.

Dalam bidang ilmu manajemen terdapat beberapa konsentrasi khusus yang berperan sentral dalam sebuah perusahaan jasa, diantaranya pemasaran, operasi, dan sumber daya manusia. Untuk itu, organisasi jasa, termasuk Perguruan Tinggi juga harus menggunakan konsep pemasaran secara internal kepada karyawan, yang dikenal dengan Pemasaran Internal. Kotler Keller (2000) menyatakan bahwa pemasaran jasa tidak hanya membutuhkan pemasaran eksternal tetapi juga pemasaran internal (internal marketing). Jadi, pemasaran internal merupakan pemasaran yang diperuntukkan bagi kepuasan karyawan pada perusahaan.

Pemasaran internal sangat penting karena pemasaran internal merupakan cara terbaik untuk membantu karyawan dalam membuat hubungan emosional yang kuat untuk produk atau jasa yang perusahaan jual. Penulis dan peneliti terdahulu, seperti Rr. Arini Chikita Selfia Sentana (2017) menyatakan bahwa perusahaan jasa yang sukses harus terlebih dahulu menjual pekerjaan kepada karyawan sebelum dapat menjual jasanya kepada pelanggan. Dalam penelitian ini penulis menguji peran kepuasan sebagai variabel mediasi dalam kepercayaan, kepuasan dan hubungan loyalitas.

Motivasi kedua dari penelitian ini adalah fenomena keluhan yang dihadapi Departemen Administrasi Akademik Universitas X. Keluhan staf bidang akademik meningkat dari tahun ke tahun (lihat Tabel 1), sebaliknya kinerja pegawai tersebut semakin meningkat. Selanjutnya keluhan berasal dari pegawai yang berkinerja baik dan loyal, artinya berasal dari pegawai yang telah bekerja di organisasi selama 5 tahun atau lebih. 
Tabel 1 Keluhan Pegawai dan rata-rata lama kerja pengabdian di Universitas X Bandung

\begin{tabular}{|c|c|c|c|c|c|c|c|}
\hline \multirow{2}{*}{ No. } & \multirow{2}{*}{ Departemen } & \multicolumn{5}{|c|}{ Pengaduan per tahun } & \multirow{2}{*}{$\begin{array}{c}\text { Ag. Pengabdian } \\
\text { (tahun) }\end{array}$} \\
\hline & & 2016 & 2017 & 2018 & 2019 & 2020 & \\
\hline 1 & $\begin{array}{l}\text { Departemen Sumber Daya } \\
\text { Manusia }\end{array}$ & 43 & 48 & 56 & 62 & 74 & 10,25 \\
\hline 2 & $\begin{array}{l}\text { Departemen Administrasi } \\
\text { Akademik }\end{array}$ & 27 & 30 & 35 & 38 & 43 & 13 \\
\hline 3 & $\begin{array}{l}\text { Departemen Administrasi } \\
\text { Rektorat }\end{array}$ & 40 & 43 & 50 & 55 & 60 & 11,9 \\
\hline
\end{tabular}

Pegawai di Perusahaan jasa merupakan pelanggan internal, maka setiap keluhan harus diperhatikan dan ditangani dengan hati-hati sebagai pelanggan eksternal. Salah satu cara untuk memasarkan perusahaan kepada pelanggan internal adalah melalui pemahaman bahwa adanya kepuasan karyawan (Trel'ová \& Olšavský, 2017; Krismajayanti dan Darma, 2021; Wulandari dan Darma, 2021; Wardana dan Darma, 2020; Kusnadi dan Darma, 2018). Jika perusahaan dapat membuat karyawan puas dan akibatnya menciptakan loyalitas, maka perusahaan akan memiliki keunggulan bersaing, karena keunggulan bersaing dapat berasal dari kepuasan karyawan. Selain itu, beberapa peneliti seperti Idul Fitri (2011) dan Lastrini dan Adnyani (2019) menemukan bahwa kepuasan berpengaruh terhadap loyalitas. Karyawan merupakan segmen penting dari pemangku kepentingan organisasi; Komitmen karyawan memainkan peran penting dalam efektivitas dan stabilitas organisasi (Ogunjinmi et al., 2014; Darma et al., 2019). Tujuan dari penelitian ini adalah untuk menganalisis penerapan pemasaran internal kepada entitas pelayanan yaitu Universitas X, melalui hubungan antara kepercayaan, komitmen, kepuasan, dan loyalitas.

\section{Pemasaran Internal}

Gronroos (2006) mengemukakan bahwa ada tiga fungsi manajemen yang memainkan peran sentral dalam sebuah perusahaan jasa: pemasaran, operasi, dan sumber daya manusia. Gronroos (2006) menjelaskan bahwa pengelolaan jasa perlu memperhatikan keterpaduan tiga fungsi perusahaan, yaitu Pemasaran, Operasi, dan Sumber Daya Manusia. Hal ini juga berarti bahwa manajemen jasa harus memiliki pemahaman yang luas tentang ketiga bidang tersebut, tidak dapat dipisahkan satu sama lain. Berdasarkan pemahaman akan pentingnya 
mempertimbangkan ketiga bidang jasa manajemen tersebut, maka konsep pemasaran internal muncul sebagai salah satu konsep yang penting dalam pengelolaan jasa.

Lovelock (2001: 8) menjelaskan pemasaran dalam organisasi jasa dapat dilihat sebagai dorongan strategis yang dikejar oleh manajemen puncak, sebagai sekumpulan aktivitas fungsional yang dilakukan oleh manajer lini, atau sebagai orientasi yang digerakkan oleh pelanggan untuk seluruh organisasi. Konsep pemasaran jasa berawal dari bidang pemasaran secara umum yang berkonsentrasi pada cara agar setiap orang yang terlibat dalam penyampaian jasa dapat terus menerus meningkatkan kualitas interaksi dan pelayanan kepada pelanggan (Gummesson, 1996; Maharani dan Darma, 2018; Wandari dan Darma, 2021; Wahyuni dan Darma, 2019; Agung dan Darma, 2019; Dharmayanti dan Darma, 2020; Pradnyawati dan Darma, 2021; Karniawati dan Darma, 2021 Maharani dan Darma, 2018; Handika dan Darma, 2018). Penggunaan konsep ini sekarang tersebar luas dan telah diterima di semua bentuk organisasi.

\section{Kepercayaan dan Kepuasan}

Rousseau, et al. (1998) mendefinisikan kepercayaan sebagai bagian psikologis yang terdiri dari keadaan pasrah untuk menerima kekurangan berdasarkan ekspektasi positif dari niat atau perilaku orang lain. Mayer (1995) mendefinisikan kepercayaan sebagai keinginan pihak untuk tunduk / menerima tindakan pihak lain berdasarkan harapan bahwa pihak lain akan melakukan sesuatu tindakan tertentu yang penting bagi mereka yang memberikan kepercayaan, kemampuan untuk memantau atau mengontrol pihak lain. Definisi kepercayaan yang diungkapkan oleh Rousseau, et al. (1998) dan Mayer (1995) mengemukakan bahwa pegawai yang mempercayai perusahaan akan membuat orang-orang tersebut bekerja dengan baik dan patuh mengikuti kemauan organisasi, sehingga pemasaran perusahaan kepada karyawan agar dapat dipercaya adalah penting.

Luo (2002) menggambarkan kepercayaan sebagai variabel yang digunakan secara luas dalam berbagai disiplin ilmu, termasuk di bidang psikologi sosial, sosiologi, perilaku organisasi, manajemen strategis, dan Bisnis Internasional. Hal ini didukung juga oleh penelitian dari Swari dan Darma (2019). Pendapat Luo (2002) mengemukakan bahwa kepercayaan merupakan variabel penting untuk dieksplorasi. Kunci yang sangat penting dalam membangun kepercayaan yang tinggi dalam organisasi adalah mencapai hasil, bertindak dengan integritas, dan menunjukkan kepedulian. Tingkat kepercayaan yang meningkat membutuhkan keseimbangan dari hal-hal penting yang telah disebutkan di atas, walaupun terdapat konflik antar pihak dalam organisasi. Keseimbangan membutuhkan desain organisasi 
yang dapat mendukung kepercayaan, baik struktur organisasi maupun budaya informal. Hal ini dapat dilihat dari studi Matzler dan Renzl (2006) terhadap 665 karyawan sektor utilitas yang mengungkapkan bahwa kepercayaan rekan kerja dan kepercayaan pada manajemen merupakan prediktor kuat dari kepuasan karyawan. Juga dalam karya Chiou dan Droge (2006) yang menemukan bahwa kepercayaan secara positif mempengaruhi kepuasan secara keseluruhan.

Mengacu pada konsep dan definisi dari Luo (2002), Rousseau, etal. (1998), Mayer (1995), Matzler dan Renzl (2006) dan Chiou dan Droge (2006), maka hipotesis pertama dari penelitian ini adalah:

\section{H1: Kepercayaan berhubungan positif dengan Kepuasan.}

\section{Komitmen dan Kepuasan}

Beberapa peneliti di bidang pemasaran mengartikan komitmen sebagai keinginan atau sikap terhadap pilihan defensif atau tidak ada perubahan yang stabil (Dwyer, dkk., 1987; Morgan dan Hunt, 1994; Pritchard, dkk., 1998). Sedangkan kepuasan - dalam bidang pemasaran - didefinisikan oleh Oliver (1997) sebagai penilaian bahwa suatu fitur produk atau layanan, atau produk atau layanan itu sendiri, memberikan (atau menyediakan) tingkat pemenuhan terkait konsumsi yang menyenangkan, termasuk tingkat di bawah atau di atas pemenuhan. Pengertian Oliver (1997) sejalan dengan kepuasan kerja yang dikemukakan oleh Locke yang dikutip oleh Pinder (1984) yang menjelaskan bahwa kepuasan kerja merupakan reaksi emosional yang dihasilkan dari persepsi bahwa pekerjaan seseorang dapat memenuhi atau memungkinkan pemenuhan kebutuhan seseorang. Dapat dilihat bahwa kedua definisi ini memiliki arti yang sama seperti yang dijelaskan Kotler dan Keller (2009) bahwa kepuasan mencerminkan penilaian seseorang atas kinerja yang dirasakan (atau hasil) suatu produk dalam hubungannya dengan ekspektasi. Perbedaan hanya pada bentuk produk yang memuaskan. Untuk pelanggan eksternal bentuk produk merupakan hasil produsen sedangkan untuk pelanggan internal bentuk produk merupakan jasa perusahaan itu sendiri. Lebih lanjut, Oliver (1993) melihat kepuasan sebagai variabel akumulatif yang bersifat afektif. Mogotsi (2011) menemukan bahwa kepuasan kerja dan komitmen organisasi berkorelasi positif secara signifikan.

Meyer dan Allen (1991) awalnya mengembangkan tiga komponen komitmen, yaitu "komitmen afektif", "komitmen normatif", dan "komitmen kontinu", sebagai tambahan, Meyer et al. (2004) menyatakan bahwa komitmen afektif memiliki korelasi positif paling kuat dengan prestasi kerja, perilaku anggota organisasi, dan kehadiran, diikuti oleh komitmen normatif. Komitmen berkelanjutan cenderung tidak berhubungan, atau berhubungan negatif, dengan 
perilaku ini. Berdasarkan definisi komitmen sebagai sikap (Dwyer, et al., 1987; Morgan dan Hunt, 1994; Pritchard, et al., 1998), kepuasan sebagai variabel kumulatif yang efektif (Oliver, 1992), temuan Mogotsi (2011), dan Meyer et al (2004) maka hipotesis kedua dari penelitian ini adalah:

\section{H2: Komitmen berhubungan positif dengan kepuasan}

\section{Kepuasan dan Loyalitas}

Hipotesis ketiga penelitian ini dikembangkan berdasarkan beberapa penelitian di bidang jasa dan e-commerce. Penelitian Yang dan Peterson (2004) menunjukkan pengaruh kepuasan terhadap loyalitas. Selain itu, Yang dan Peterson (2004) juga mengungkapkan bahwa kepuasan merupakan variabel yang memediasi hubungan antara nilai yang dirasakan dan loyalitas. Idul Fitri (2011) mengungkapkan bahwa loyalitas sangat dipengaruhi oleh kepuasan. Hal tersebut didukung juga oleh penelitian dari Kolo dan Darma (2020). Anderson dan Srinivasan (2003) mengungkapkan bahwa kepuasan berpengaruh terhadap loyalitas, selain itu penelitian ini juga mengungkapkan bahwa hubungan antara kepuasan dan loyalitas dimoderasi oleh 'faktor tingkat individu dan faktor tingkat bisnis perusahaan'.

Hasil penelitian Parvez dan Akbar (2009) menunjukkan bahwa kepuasan secara signifikan berhubungan positif dengan loyalitas. Matzler dan Renzl, (2006) menemukan bahwa kepercayaan rekan kerja dan kepercayaan manajemen adalah prediktor kuat dari kepuasan karyawan, kemudian kepuasan karyawan juga ditemukan yang, pada gilirannya, mempengaruhi loyalitas karyawan. Berdasarkan Studi Yang dan Peterson (2004), Idul Fitri (2011), Anderson dan Srinivasan (2003), Akbar dan Parvez (2009), serta Matzler dan Renzl (2006), maka hipotesis ketiga dari penelitian ini adalah:

\section{H3: Kepuasan berhubungan positif dengan loyalitas}

\section{Kepercayaan dan Loyalitas}

Idul Fitri (2011) selain mengungkapkan pengaruh kepuasan terhadap loyalitas, juga ditemukan bahwa kepercayaan berpengaruh terhadap loyalitas. Sedangkan penelitian Akbar dan Parvez (2009) menunjukkan bahwa selain kepuasan, kepercayaan juga memiliki hubungan yang positif secara signifikan dengan loyalitas. Lebih lanjut Parvez dan Akbar (2009) juga mengungkapkan bahwa kepuasan menjadi mediator antara kualitas layanan yang dirasakan dan loyalitas. Harrisand Goode (2004) mengungkapkan bahwa dalam bisnis online, kepercayaan merupakan variabel sentral dalam hubungan antara kualitas layanan, nilai yang dirasakan, kepuasan, kepercayaan, dan loyalitas. Mereka menemukan bahwa kepercayaan memiliki 
hubungan yang signifikan dengan loyalitas. Agustin dan Singh (2005) mengungkapkan bahwa ada hubungan antara kepercayaan dan niat untuk setia (niat loyalitas). Chiou dan Droge (2006) juga menemukan bahwa kepercayaan berhubungan positif dengan kesetiaan sikap. Merujuk pada Harris dan Goode (2004) Agustin dan Singh (2005) dan Chiou dan Droge (2006), maka hipotesis keempat dari penelitian ini adalah:

\section{H4: Kepercayaan berhubungan positif dengan loyalitas}

\section{Komitmen dan Loyalitas}

Hipotesis kelima dari penelitian ini didasarkan pada beberapa penelitian di bidang pemasaran relasional. Penulis menemukan bahwa pemasaran relasional merupakan pendekatan terbaik untuk penelitian ini, karena konsep pemasaran relasional, seperti kepuasan, komitmen, dan kepercayaan juga tersirat dalam bidang perilaku organisasi sebagai elemen Organizational Citizenship Behavior (OCB). Beberapa analis pemasaran hubungan termasuk Pritchard et al. (1999), Moon (2000), McDougall dan Levesque (2000), Yoon (2002), Zulganef (2006), dan Sati dan Susanto (2013) menganalisis korelasi antara komitmen dan loyalitas.

Pritchard dkk. (1999) menemukan hubungan antara komitmen dan niat membeli kembali konsumen hotel dan maskapai penerbangan. Moon (2000), Yoon (2002) mengungkapkan bahwa kepuasan, kepercayaan, dan komitmen pelanggan online secara signifikan berkorelasi dengan niat mereka terhadap loyalitas, dan Zulganef (2006) menemukan korelasi antara komitmen dan niat untuk loyalitas dalam hubungan pemasaran jasa Sebaliknya, Sati dan Susanto (2013) menemukan bahwa tidak terdapat hubungan yang signifikan antara komitmen dan loyalitas. Penulis menemukan bahwa perbedaan hasil Sati dan Susanto (2013) dengan Zulganef (2006), Pritchard et al (1999), Moon (2000), dan Yoon (2002), harus diverifikasi dalam bidang pemasaran internal, maka hipotesis kelima dari penelitian ini adalah:

\section{H5: Komitmen berhubungan positif dengan loyalitas.}

\section{Pengaruh mediasi atas kepuasan terhadap hubungan antara kepercayaan, komitmen, dan loyalitas.}

McKinnon dan Dwyer (1993) mengungkapkan bahwa salah satu tujuan dalam menganalisis variabel mediasi adalah untuk memahami apakah variabel dalam variabel dependen benar-benar berpengaruh terhadap variabel dependen atau melalui variabel lain sebagai perantara (mediating), sehingga variabel intermediasi perlu dilakukan. diperhitungkan atau diperkuat posisinya. Lebih lanjut McKinnon dan Fairchild (2009) mengungkapkan bahwa melalui investigasi peran variabel mediasi hubungan yang ada akan memberikan gambaran 
yang lebih detail dari suatu hubungan. Variabel yang diuji, yang menjadi fokus penelitian ini adalah kepuasan sebagai variabel yang memediasi hubungan antara kepercayaan dan komitmen dengan loyalitas, dalam hal ini untuk menguji apakah variabel kepercayaan dan komitmen benar-benar dapat memberikan pengaruh langsung terhadap loyalitas atau melalui kepuasan (Lewis , 1996: 57; Caruna dan Calleya, 1998), sehingga peran kepuasan dalam menentukan loyalitas perlu digali. Mengingat pentingnya variabel kepuasan dalam mengelola layanan khususnya karyawan yang merasa puas akan berpengaruh terhadap kepuasan pelanggan eksternal, maka hipotesis keenam dan ketujuh dari penelitian ini adalah:

\section{H6: Hubungan antara Kepercayaan dan Loyalitas dimediasi oleh kepuasan}

\section{H7: Hubungan antara Komitmen dan Loyalitas dimediasi oleh kepuasan.}

\section{METODE PENELITIAN}

Populasi penelitian ini adalah seluruh staf departemen akademik, departemen sumber daya manusia dan departemen adiministrasi rektorat di Universitas X Bandung yang berjumlah 500 pegawai dan memiliki masa kerja 5 sampai 10 tahun. Besar sampel 222 yang ditentukan melalui rumus Slovin. Pengumpulan data dilakukan melalui simple random sampling dan kuesioner yang diberikan sendiri. Dari 222 responden yang menjawab hanya 162, maka tingkat tanggapan penelitian ini adalah 72,9\%. Kepercayaan dan Komitmen diukur dengan 6 komponen, kepuasan 3 komponen, dan loyalitas sebanyak 5 komponen, semua komponen menggunakan skala likert. Sedangkan untuk memediasi efek kepuasan, penulis menggunakan empat langkah dari Baron dan Kenny (1986), Kenny (http://davidakenny.net/cm/mediate.htm), dan Saltson (2015).

\section{HASIL DAN PEMBAHASAN}

\section{Analisis Faktor Konfirmatori, Reliabilitas, dan Regresi}

Pemurnian data dilakukan melalui analisis faktor konfirmatori, diperoleh hasil bahwa 3 dari 6 komponen kepercayaan, 3 dari 6 komponen komitmen, 1 dari 3 komponen kepuasan, dan 3 dari 5 komponen loyalitas, tidak dikonfirmasi. Uji reliabilitas terhadap keempat variabel menunjukkan bahwa semua variabel melebihi 0,6 yang berarti semua variabel reliabel. Cronbach alpha untuk komponen Kepercayaan adalah 0,653; Komitmen adalah 0,661; Kepuasan 0.678; dan Loyalitas adalah 0,815. Model regresi yang digunakan dalam pengujian kepuasan sebagai peran mediasi dalam hubungan antara kepercayaan dan loyalitas, dan komitmen dan loyalitas adalah: 
eqn (1): $\mathrm{Y}=\mathrm{a}+\mathrm{bX}+\mathrm{e} 1$

Peran mediasi kepuasan dalam hubungan antara Kepercayaan dan Loyalitas

Tabel 2. Regresi Kepercayaan, Kepuasan, dan Loyalitas

\begin{tabular}{|c|c|c|c|c|c|c|c|}
\hline Tahap & & Variabel & & & & & \\
\hline & IV & MV & DV & $\mathbf{R}^{2}$ & Coeff. & t & Sig (p) \\
\hline 1 & Trust & & Loyalty & 0.019 & 0.115 & 1.749 & 0.082 \\
\hline 2 & Trust & Satisfaction & & 0.209 & 0.759 & 6.497 & 0.000 \\
\hline 3 & & Satisfaction & Loyalty & 0.039 & 0.101 & 2.561 & 0.011 \\
\hline 4 & Trust & Satisfaction & Loyalty & \multicolumn{4}{|c|}{ Not Conduct } \\
\hline
\end{tabular}

Tabel 2 menunjukkan:

1. Pengolahan data tahap pertama menunjukkan bahwa Kepercayaan tidak signifikan berpengaruh terhadap Loyalitas, koefisien regresi b sebesar 0.115 dan p-value 0.082 (p>0.05), dengan demikian dinyatakan bahwa Kepercayaan berpengaruh tidak signifikan terhadap Loyalitas karyawan urusan akademik

2. Pengolahan data tahap kedua menunjukkan bahwa Kepercayaan berhubungan secara signifikan dan positif dengan Kepuasan, dimana koefisien regresi b adalah 0,759 dan p-value 0,000 (p $<0,05)$, maka dari itu dijelaskan bahwa Kepercayaan berpengaruh signifikan terhadap Kepuasan pegawai urusan akademik

3. Pengolahan data tahap ketiga menunjukkan bahwa Kepuasan signifikan dan berhubungan positif dengan Loyalitas, dimana koefisien regresi b adalah 0.101 dan p-value 0.011 ( $<<0.05$ ), maka dari itu dijelaskan bahwa kepuasan berpengaruh signifikan terhadap loyalitas karyawan urusan akademik

Tiga langkah pengolahan data menunjukkan bahwa kepuasan dimediasi sepenuhnya korelasi antara Kepercayaan dan Loyalitas, karena tidak ada pengaruh langsung kepercayaan terhadap loyalitas. Hal ini ditunjukkan dengan regresi tahap pertama, sehingga penulis tidak perlu melanjutkan ke tahap keempat proses tersebut. 


\section{Peran mediasi kepuasan dalam hubungan antara Komitmen dan Loyalitas}

Tabel 3 menunjukkan :

1. Tahap pertama menunjukkan bahwa Komitmen berpengaruh signifikan terhadap Loyalitas, dimana koefisien regresi b sebesar 0,145 dan p-value sebesar 0,031 ( $p<0,05)$, dengan demikian dinyatakan bahwa Komitmen berpengaruh signifikan terhadap Loyalitas karyawan bidang akademik

2. Tahap kedua menunjukkan bahwa Komitmen berhubungan secara signifikan dan positif dengan Kepuasan, dimana koefisien regresi b adalah 0,085 dan p-value adalah 0,000 ( $p<0,05)$, maka dari itu dijelaskan bahwa Komitmen berpengaruh signifikan terhadap Kepuasan pegawai urusan akademik

3. Ketiga Tahap menunjukkan bahwa Kepuasan berhubungan secara signifikan dan positif dengan Loyalitas, dimana koefisien regresi b adalah 0,101 dan $\mathrm{p}$-value 0,011 ( $\mathrm{p}<0,05)$, dan t Oleh karena itu dijelaskan bahwa kepuasan berpengaruh signifikan terhadap loyalitas karyawan bagian akademik.

4. Tahap keempat dilakukan melalui regresi hierarkis, dan hasilnya dapat dilihat pada Tabel 4.

5. Tabel 3. dan 4. menunjukkan bahwa hubungan antara Komitmen dan loyalitas adalah signifikan, hubungan antara Komitmen dan Kepuasan signifikan, hubungan antara Kepuasan dan Loyalitas signifikan, dan hubungan antara Komitmen dan loyalitas tidak signifikan pada fungsi $\mathrm{Y}=\mathrm{f}$ (Komitmen, Kepuasan) atau hubungan Komitmen dan Kepuasan dengan $\mathrm{Y}$ tidak signifikan. signifikan ketika diintervensi oleh kepuasan, nilai p komitmen dan loyalitas berubah dari 0,031 (signifikan) menjadi 0,131 (tidak signifikan); maka dapat diputuskan bahwa hubungan antara Komitmen dan Loyalitas dimediasi sepenuhnya oleh Kepuasan.

Tabel 3. Regresi Komitmen, Kepuasan, dan Loyalitas

\begin{tabular}{|c|c|c|c|c|c|c|c|}
\hline Tahap & & Variabel & & & & & \\
\hline & IV & MV & DV & $\mathbf{R}^{2}$ & Coeff. & $\mathbf{t}$ & Sig (p) \\
\hline 1 & Commitment & & Loyalty & 0.029 & 0.145 & 2.178 & 0.031 \\
\hline 2 & Commitment & Satisfaction & & 0.085 & 0.490 & 3.845 & 0.000 \\
\hline 3 & & Satisfaction & Loyalty & 0.039 & 0.101 & 2.561 & 0.011 \\
\hline
\end{tabular}


Tabel 4. Koefisien Regresi Komitmen, Kepuasan, dan Loyalitas ${ }^{\mathrm{a}}$

\begin{tabular}{lccccc}
\hline Model & \multicolumn{2}{c}{ Unstandardized Coefficients } & Standardized Coefficients & t & Sig. \\
\cline { 2 - 5 } & B & Std. Error & Beta & \\
\hline 1. (Constant) & 3,402 & 0,258 & 0,170 & 13,193 & 0,000 \\
KOMITMEN & 0,145 & 0,066 & & 2,178 & 0,031 \\
2. (Constant) & 3,272 & 0,264 & 0,122 & 12,413 & 0,000 \\
KOMITMEN & 0,104 & 0,069 & 0,163 & 1,517 & .131 \\
KEPUASAN & 0,083 & 0,041 & & 2,019 & 0,045 \\
\hline
\end{tabular}

a. Variabel Terikat: LOYALITAS

\section{PENUTUP}

Penelitian ini menunjukkan bahwa kepuasan masih menjadi pertimbangan utama yang menyebabkan loyalitas, karena ada peran kepuasan yang dimediasi penuh baik dalam hubungan kepercayaan dan loyalitas serta komitmen dan loyalitas. Artinya, baik kepercayaan maupun komitmen harus dielaborasi menjadi kepuasan terlebih dahulu sebelum berubah menjadi loyalitas. Artinya perguruan tinggi di kota Bandung harus mengembangkan kepuasan karyawan untuk bertahan dalam persaingan ekonomi tanpa batas. Ada perbedaan penting antara Kepercayaan dan Komitmen. Kepercayaan tidak ada hubungannya dengan loyalitas, sehingga harus benar-benar dimediasi oleh kepuasan untuk mengarah pada loyalitas, artinya Kepercayaan merupakan variabel yang tidak dapat mendorong loyalitas tanpa kepuasan. Di sisi lain, Komitmen berpengaruh langsung terhadap loyalitas, artinya komitmen juga memiliki peran penting dalam membentuk loyalitas. Dalam penelitian ini Komitmen menunjukkan lebih independen dari pada Kepercayaan, artinya komitmen dapat berdampak langsung pada loyalitas, sedangkan Kepercayaan harus dimediasi oleh kepuasan. Sehingga manajemen perguruan tinggi di kota Bandung dapat menjadikan komitmen sebagai prioritas daripada kepercayaan, meskipun kepercayaan memiliki pengaruh tidak langsung terhadap loyalitas, namun tetap dapat berperan signifikan melalui kepuasan, sehingga manajemen tetap harus mengembangkan kepercayaan untuk menjadikan loyalitas. 


\section{DAFTAR PUSTAKA}

Agustin, C., and J. Singh (2005). Curvilinear Effects of Consumer Loyalty Determinants in Relational Exchanges, Journal of Marketing Research, XLII: 96-108.

Agung, N.F.A., and Darma, G.S. (2019). Opportunities and Challenges of Instagram Algorithm in Improving Competitive Advantage, International Journal of Innovative Science and Research Technology, 4 (1): 743-747.

Akbar and Parvez (2009). Impact Of Service Quality, Trust, and Customer Satisfaction On Customers Loyalty, ABAC Journal, 29 (1): 24-38.

Anderson, R.E., and S.S. Srinivasan. (2003). e-Satisfaction and e-Loyalty: A Contingency Framework, Psychology \& Marketing, 20 (2): 123-138.

Cahill, D.J. (1995). The managerial implications of the learning organization: a new tool for internal marketing, Journal of Services Marketing, 9 (4): 43 - 51.

Caruana, A., and P. Calleya. (1998). The effect of internal marketing on organisational commitment among retail bank managers, International Journal of Bank Marketing, 16 (3): 108-116.

Chiou, J-S., and C. Droge. (2006). Service Quality, Trust, Specific Asset Investment, and Expertise: Direct and Indirect Effects in a Satisfaction-Loyalty Framework, Journal of the Academy of Marketing Science, 34 (4): 613-627.

Dwyer, F. R., P. H. Schurr., \& S. Oh. (1987). Developing Buyer-Seller Relationships, Journal of Marketing, 51: 11-27.

Darma, G.S., \& Noviana, I.P.T. (2020). Exploring Digital Marketing Strategies during the New Normal Era in Enhancing the Use of Digital Payment. Jurnal Mantik, 4(3), 22572262. https://doi.org/10.35335/mantik.Vol4.2020.1084.pp2257-2262.

Darma, G.S., Wicaksono, K., Sanica, I.G., and Abiyasa, A.P. (2019). Faktor Kompensasi dan Strategi Gojek Dalam Meningkatkan Kepuasan Kerja Para Driver, JURNAL ILMIAH MANAJEMEN BISNIS DAN INOVASI UNIVERSITAS SAM RATULANGI, 6 (3): 232244.

Dewi, M.V.K., and Darma, G.S. (2019). The Role of Marketing \& Competitive Intelligence In Industrial Revolution 4.0, Jurnal Manajemen \& Bisnis, 16 (1): 1-12.

Dharmayanti, P. D., \& Darma, G. S. (2020). The Use of Instagram in Coffee Shop. International Research Journal of Management, IT \& Social Sciences, 7(4), 48-56. https://doi.org/10.21744/irjmis.v7n4.948

Eid, M. I. (2011). Determinants of E-Commerce Customer Satisfaction, Trust, and Loyalty in Saudi Arabia, Journal of Electronic Commerce Research, 12 (1): 78-93 
Gilmore, A., and D. Carson (1996). Managing and Marketing to Internal Customers. in Glyn and Barnes (Eds.) Understanding Services Management: Integrating Marketing, OrganisationalBehaviour, Operations and Human Resource Management. Chichester: John Wiley and Sons.

Gronroos, C. (2006). Adopting a service logic for marketing, Marketing Theory, 6: 317

Gummessons, E. (1996). Relationship Marketing: Its Role in the Service Economy. in Glyn and Barnes (Eds.) Understanding Services Management: Integrating Marketing, OrganisationalHarris, L. C. and M.M.H. Goode (2004). The four levels of loyalty and the pivotal role of trust: a study of online service dynamics, Journal of Retailing $\mathbf{8 0}$ : $139-158$.

Handayani, L.P.D.S., \& Darma, G. S. (2021). Pengaruh Kebijakan Pemeriksaan, Kebijakan Akses Informasi Keuangan dan Forensik Digital terhadap Kualitas Pemeriksaan Pajak. Syntax Literate; Jurnal Ilmiah Indonesia, 6(3), 1260-1272.

http://dx.doi.org/10.36418/syntax-literate.v6i3.1142

Handayani, K.A.T., and Darma, G.S. (2018). Firm Size, Business Risk, Asset Structure, Profitability, and Capital Structure, Jurnal Manajemen \& Bisnis, 15 (2): 48-57.

Handika, M.R., and Darma, G.S. (2018). Strategi Pemasaran Bisnis Kuliner Menggunakan Influencer Melalui Media Sosial, Jurnal Manajemen \& Bisnis, 15 (2): 188-199.

Karniawati, N.P.A., Darma, G. S., Mahyuni, L.P., \& Sanica, I.G. (2021). COMMUNITY PERCEPTION OF USING QR CODE PAYMENT IN ERA NEW NORMAL. PalArch's Journal of Archaeology of Egypt/Egyptology, 18(1), 3986-3999.

Krismajayanti, N.P.A., \& Darma, G. S. (2021). Eksplorasi Loyalitas Millennial Terhadap Brand Apple. Prestige or Needs?. Jurnal Manajemen dan Bisnis (Performa), 18(3), $32-44$.

Kusnadi, D.S., and Darma, G.S. (2018). Menakar Implementasi Green Marketing Pada Usaha Kecil Menengah, Jurnal Manajemen \& Bisnis, 15 (1): 1-18.

Kolo, S.M., and Darma, G.S. (2020). Faktor-Faktor Terpenting Yang Mempengaruhi Kepuasan dan Loyalitas Pelanggan Pengguna Jaringan 4G di Denpasar, Jurnal Manajemen Bisnis, 17 (1): 57-74.

Kotler, P., and K.L., Keller. (2009). Marketing Management. London: Pearson International Edition.

Lewis, B.R. (1996). Customer Care in Services. in Glyn and Barnes (Eds.) Understanding Services Management: Integrating Marketing, Organisational Behaviour, Operations and Human Resource Management. Chichester: John Wiley and Sons. 
Lovelock, C.H. (1996). Managing Services: The Human Factor, in Glyn and Barnes (Eds.) Understanding Services Management: Integrating Marketing, OrganisationalBehaviour, Operations and Human Resource Management, Chichester: John Wiley and Sons.

Lovelock, C. (2001). Services Marketing: People, Technology, Strategy. Upper Saddle River, New Jersey: Prentice Hall.

Luo, Y. (2002). Building Trust in Cross-Cultural Collaborations: Toward a Contingency Perspective, Journal of Management, 28; 669.

Maharani, I.G.A.P.D., and Darma, G.S. (2018). Consumer Purchasing Behavior Analysis on Impulse Buying, Jurnal Manajemen \& Bisnis, 15 (3): 16-37.

Murti, K.G.K., \& Darma, G. S. (2021). Jalan Terjal Online Travel Platform Hadapi Pandemi. Syntax Literate; Jurnal Ilmiah Indonesia, 6(5), 2280-2296. http://dx.doi.org/10.36418/syntax-literate.v6i5.2703

MacKinnon, D.P., and J.H. Dwyer. (1993). Estimating Mediated Effects in Prevention Studies, Evaluation Review, 17 (2): 144-158.

and A.J. Fairchild. (2009). Current Directions in Mediation Analysis, Curr Dir Psychol Sci, 18 (1): 16-20.

MatzlerdanRenzl. (2006). The Relationship between Interpersonal Trust, Employee Satisfaction, and Employee Loyalty, Total Quality Management, 17 (10): 1261-1271. McDougall, G. H.G., and T. Levesque. (2000). Customer Satisfaction With Services: putting perceived value into the equation, Journal of Services Marketing, 14 (5): 392-410

Meyer, J. P., T. E. Becker, and C. Vandenberghe. (2004). Employee Commitment and Motivation: A Conceptual Analysis and Integrative Model, Journal of Applied Psychology, 89 (6): 991-1007.

Mogotsi, I.C. (2011). Modelling the Relationships between Knowledge Sharing, Organisational Citizenship, Job Satisfaction, and Organisational Commitment among School Teacher in Botswana, Afr.J.Lib, Arch. \&Inf.Sc, 21 (1): 41-58.

Moon, Y. (2000). Intimate Exchanges: Using Computers to Elicit Self-Disclosure from Consumers, Journal of Consumer Research, 26: 323-339.

Morgan, R. M., \& S. D. Hunt. (1994). The Commitment- Trust Theory of Relationship Marketing, Journal of Marketing, 58: 20-3.

Murphy, J. T. (2006). Building Trust in Economic Space, Progress in Human Geography, 30, 4: 427-450.

Naisbitt, J. (1994). Global Paradox, translated by Drs.Budijanto. Jakarta: Binarupa Aksara. 
Ogunjinmi, A. A., Onadeko, S. A., Labedo, olugbenga J., Ogunjinmi, K. O., \& Agric, M. (2014). Personal Characteristics and Training Opportunities As Determinants of Organisational Commitment Among Nigeria National Parks' Employees, European Scientific Journal, 10 (5): 221-230.

Oliver, R.L. (1993). Cognitive, Affective, and Attribute Bases of the Satisfaction Response, Journal of Consumer Research, 20, 418-430.

(1997) Satisfaction: A Behavioral Perspective on The Consumer. New York: The McGraw-Hill Companies, Inc.

Pinder, C.C. (1984). Work Motivation: Theory, Issues, and Applications. Glenview, Illinois London: Scott, Foresman and Company.

Pradnyawati, N.M.A.A., \& Darma, G. S. (2021). Jalan Terjal Transaksi Non Tunai Pada Bisnis UMKM. MEDIA BINA ILMIAH, 15(10), 5505-5512. https://doi.org/10.33758/mbi.v15i10.1081

Pritchard, M. P., M. E. Havitz, and D. R. Howard (1999). Analyzing the Commitment-Loyalty Link in Service Contexts, Journal of the Academy of Marketing Science, 27 (3): 333348.

Priskila, S., \& Darma, G.S. (2020). Employee Perception of Brand Value in the Jewelry Industry. Journal of Economics, Business, \& Accountancy Ventura, 23 (2). http://dx.doi.org/10.14414/jebav.v23i2.2281.

Rivaldo, I. M. G., Lestari, N.P.N.E., \& Darma, G.S., \& Gorda, A.A.N.E.S. (2021). Integrating The Credit Lending Strategies of Multi-Purpose Cooperatives (a Case Study at KSU Dauh Ayu in Denpasar). Jurnal Mantik, 4(4), 2318-2324. https://doi.org/10.35335/mantik.Vol4.2021.1138.pp2318-2324.

Rousseau, D. M., Sitkin, S. B., Burt, R. S., \&Camerer, C. 1998. Not so different after all: A cross-discipline view of trust. Academy of Management Review, 23 (3): 393-421.

Saltson, E. (2015). The Mediating and Moderating Effects of Motivation in The Relationship Between Perceived Organizational Support and Employee Job Performance, International Journal of Economics, Commerce and Management, III (7): 654-667.

Sati, Z. S., and U. Susanto (2013). The Existence of I.Oyaity In Indonesia Ministery Education Regutation On Etectronic Text Book (Study of Vocationat High School's Etectronic Text Book in Bandung), Jurnol Monojemen Teori don Teropon, 6(3), Departemen Manajemen, Fakultas Ekonomi dan Bisnis Universitas Airlangga, Surabaya. 
Shavitri, L.P.D., \& Darma, G.S. (2020). Pengaruh Implementasi Kebijakan Pemeriksaan dan Forensik Digital terhadap Kualitas Pemeriksaan dan Keberhasilan Penerimaan Pajak. E-Jurnal Akuntansi, 30(10), 2682 - 2697. https://doi.org/10.24843/EJA.2020.v30.i10.p19

Shawyun, T. (2014). Landscape of HEI and Quality Challenges in AEC 2015, International Journal of Business and Management, II (2): 71-93.

Sudiwedani, A., \& Darma, G.S. (2020). Analysis of the effect of knowledge, attitude, and skill related to the preparation of doctors in facing industrial revolution 4.0, Bali Medical Journal, 9(2), 524-530. https://dx.doi.org/10.15562/bmj.v9i2.1895.

Swari, D.A.K.B.A., and Darma, G.S. (2019). Kepercayaan Lintas Generasi Dalam Penggunaan Social Media dan Electronic Word of Mouth, Jurnal Manajemen Bisnis, 16 (4): 145161.

Syahruddin, M., Rosmayati, M., Bakti, D., \& L. Henuk, Y. (2017). Public Policies for Higher Education Systems in 10 ASEAN Associate Countries. https://doi.org/10.2991/icosop16.2017.41.

Trel'ová, S., \& Olšavský, F. (2017). Employee Satisfaction with Training Opportunities and its Relation to Internal Marketing, HOLISTICA - Journal of Business and Public Administration, 8 (2): 7-16. https://doi.org/10.1515/hjbpa-2017-0009.

Wandari, N.K.M.A., \& Darma, G. S. (2021). Pengelolaan Karakter Green-Behavior Pada Generasi Milenial Dalam Meningkatkan Minat Penggunaan Green-Product. Jurnal Nusantara Aplikasi Manajemen Bisnis, 6(1), 49-61.

https://doi.org/10.29407/nusamba.v6i1.14778

Wahyuni, N.W.S., and Darma, G.S. (2019). Mobile Advertising, Product Social Value dan Purchase Intention pada Instagram, Jurnal Manajemen Bisnis, 16 (4): 87-101.

Wardana, I.M.A., \& Darma, G.S. (2020). Garment Industry Competitive Advantage Strategy During Covid-19 Pandemic. PalArch's Journal of Archaeology of Egypt / Egyptology, https://www.archives.palarch.nl/index.php/jae/article/view/2732.

Wulandari, L.P.A., \& Darma, G.S. (2020). Advertising Effectiveness in Purchasing Decision on Instagram. Journal of Business on Hospitality and Tourism, 6(2), 381-389. http://dx.doi.org/10.22334/jbhost.v6i2.220

Yang, Z., and R.T. Peterson. (2004). Customer Perceived Value, Satisfaction, and Loyalty: The Role of Switching Costs, Psychology \& Marketing, 21 (10): 799-822. 
Yoon, S. (2002). The Antecedents and Consequences of Trust in Online-Purchase Decisions, Journal of Interactive Marketing, 16 (2): 47-63.

Yong, I.D., \& Darma, G.S. (2020). Indikator Penentu Naik Turunnya Harga Saham pada Perusahaan High Deviden 20 Periode Tahun 2014-2019. Syntax Literate ; Jurnal Ilmiah Indonesia, 5(12), 1591-1610. doi:10.36418/syntax-literate.v5i12.1907.

Zulganef. (2006). The Existence of Overall Satisfaction in Service Customer Relationships, GadjahMada International Journal of Business, 8 (3), Master of Management Program Universitas Gadjah Mada. 